Leszek KARSKI

IEiB UKSW Warszawa

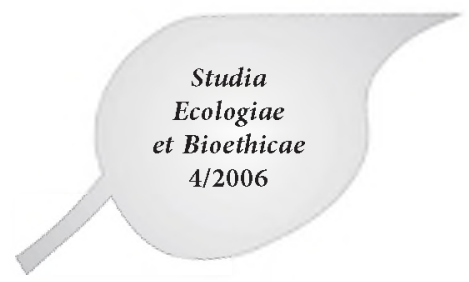

\title{
Prawa człowieka i środowisko
}

Bez wątpienia ludzka działalność powoduje znaczące problemy środowiskowe. Zarazem nie podlega dyskusji, iż te problemy często skutkują bardzo poważnymi konsekwencjami dla człowieka. Wspólny obszar dla problematyki ochrony środowiska oraz zagadnień praw człowieka już niejednokrotnie był przedmiotem rozważań przedstawicieli nauki. Również prawo, czy to na szczeblu międzynarodowym, czy krajowym, nawiązuje do tych kwestii. Jednak w tym przypadku prawodawca daleko pozostaje w tyle za osiągnięciami doktryny. Wydaje się, iż w tym obszarze niezbędne jest podsumowanie dotychczasowego dorobku w tym zakresie oraz zaproponowanie nowych kierunków, w których powinno zmierzać odkrywanie praw człowieka do środowiska. Z pewnością jednym z podstawowych zagadnień powinno być zastanowienie się nad tym, czy człowiek na obecnym poziomie rozwoju ma prawo do czystego środowiska i jak należy rozumieć to prawo.

\section{Prawa do środowiska, jako prawa człowieka}

$\mathrm{Na}$ wstępie warto przeanalizować gdzie znajdują się „korzenie" praw do środowiska.

Za źródło praw i wolności uznawana jest godność człowieka ${ }^{1}$. To właśnie godność człowieka stanowiła dla szkoły prawa natury podstawę rozwoju koncepcji praw podmiotowych w XVII wieku. W tym okresie pojawiła się idea, która ma znaczący wpływ na dzisiejsze rozumienie omawianego zagadnienia. Prawa przyrodzone człowieka wynikają z właściwości natury ludzkiej². Obecnie powszechnie przyjmuje się, iż prawa człowieka są uniwersalne, niepodzielne, wzajemnie zależne i powiązane ze sobą ${ }^{3}$. Taki wniosek z kolei implikuje stosunek praw człowieka do prawa stanowionego. Prawo pozytywne nie jest źródłem praw człowieka. Prawodawca zakreśla istniejące już prawa podmiotowe w celu zapewnienia zgodnego współżycia społecznego. Wyznacza im pewne niezbęd-

W. Jakimowicz, Publiczne prawa podmiotowe, Kraków 2002, s. 38.

Szerzej M. Piechowiak, Filozofia praw człowieka, Lublin 1999.

3 Deklaracja Wiedeńska z 1994 r. 
ne granice, dążąc do pogodzenia praw poszczególnych ludzi oraz zapewnienia poszanowanie praw ${ }^{4}$. Normy prawne nie ustanawiają podstawowych praw, one jedynie deklarują ich istnienie i gwarantują, iż państwo będzie zachowywało się w taki sposób, aby umożliwić jednostce korzystanie z praw jej przysługujących. Decyzje prawodawcze, które ustanawiają pewne uprawnienia, czy też obowiązki w sensie prawnym są tylko środkiem, który ma zapewnić poszanowanie godności człowieka 5 .

Wraz z rozwojem cywilizacji ludzkiej odkrywamy coraz więcej praw, które przysługują człowiekowi. Po usankcjonowaniu przez prawo pozytywne praw politycznych, społecznych i ekonomicznych prawodawcy stanęli przed nowym wyzwaniem - nowym prawem albo nawet całym kompleksem praw człowieka do środowiska naturalnego.

W piśmiennictwie dominuje $\mathrm{e}^{6}$ zaproponowana przez Karla Vasaka ${ }^{7}$ typologia praw człowieka. Otóż wspomniany przedstawiciel nauki wyróżnia trzy zasadnicze kategorie praw:

- prawa osobiste i polityczne

- prawa gospodarcze, socjalne i kulturalne

- prawa solidarnościowe.

Prawo człowieka do środowiska były często umieszczane albo przynajmniej wiązane $z$ katalogiem praw politycznych i praw socjalnych ${ }^{8}$. Jednak włączenie omawianego prawa do odrębnej kategorii jest bardziej poprawne. W Karcie Praw Podstawowych Unii Europejskiej zaliczono prawa do środowiska do praw solidarnościowych, czyli do III rodziny - generacji ${ }^{9}$. Należy zauważyć, iż jest to kategoria, której zarówno koncepcja, jak i ujęcie poszczególnych praw składowych wykształciły się znacznie później od I i II generacji praw.

W literaturze ${ }^{10}$ wskazuje się na art. 28 Powszechnej Deklaracji Praw Człowieka, jako ogólną proklamację praw III generacji: „Każdy człowiek jest upraw-

4 W. JAKIMOWICZ, op. cit., s. 30.

5 M. Piechowiak, Prawa czlowieka w projekcie konstytucji, Rzeczpospolita z 23 maja 1995.

6 M.M. Kenig-Wit Kowska, Prawo środowiska w prawie międzynarodowym, $\mathrm{PiP} \mathrm{Nr} 8 / 2000$, s. 28; Piechowiak M., Filozofia praw..., s. 65 i n.; inaczej Zb. Hoeda, (w:) Prawa człowieka. Zarys wykładu, Hołda J. i inni, Kraków 2004, s. 11 i n.

$7 \mathrm{~K}$. VASAK (red.), The international dimensions of human rights, Volume 1, Volume 2, Paris 1982.

8 V. KARTASHKIN, Economic, social and cultural rigts (w:) The international dimensions of human rights, Volume 1, Vasak K. (red.), Paris 1982, s. 124-125; J. Sommer, Prawo do srodowiska (w:) Prawa człowieka. Model prawny, Wrocław - Warszawa - Kraków 1991, s. 962-963; Zb. Hołda op. cit., s. 12; A. Michalska, Prawa czlowieka w systemie norm międzynarodowych, Warszawa - Poznań 1982, s. 223-227.

9 Art. 37 Karty Praw Podstawowych Unii Europejskiej, The Charter of Fundamental Rights of 4 April 2000, http://www.europa.eu.int, szerzej na temat tego dokumentu - F. Jasiński, Karta Praw Podstawowych Unii Europejskiej, Warszawa 2003.

10 B. Weston, Human Rights, Human Rihgts Quarterly, Nr 3/1984, s. 266 i n. 
niony do takiego porządku społecznego i międzynarodowego, w którym prawa i wolności przedstawione w niniejszej Deklaracji mogą być w pełni realizowane". Burns Weston zakwalifikowal do tej grupy między innymi prawo do zdrowego i zrównoważonego środowiska ${ }^{11}$.

Dotychczas prawa solidarnościowe nie doczekały ogólnoświatowego umocowania traktatowego, które byłoby porównywalne do Międzynarodowych Paktów Praw Człowieka z 1966 r. Natomiast na poziomie regionalnym większość praw solidarnościowych, w tym również prawo do środowiska, znalazła się w Afrykańskiej Karcie Praw Człowieka i Ludów z 1981 r. ${ }^{12}$.

Warto zwrócić uwagę na niezwykle interesujący aspekt praw i wolności człowieka. Wraz z upływem czasu następuje stałe umacnianie godności człowieka. Wiąże się to ze wzrostem poziomu społecznego i ekonomicznego. Dlatego też materia praw jednostki jest problematyką, która charakteryzuje się znacznym i szybkim rozwojem. Osiągnięcia nauki w omawianej dziedzinie, powodują, iż prawa do środowiska powoli zaczynają tworzyć odrębną grupę praw. Niektórzy przedstawiciele nauki, podkreślając znaczenie praw do środowiska, zaliczają je już do oddzielnej IV już generacji praw człowieka ${ }^{13}$. Wydaje się, iż takie stanowisko, jest w pełni uzasadnione, ze względu na wagę oraz na specyficzny charakter tych praw.

\section{Pojęcie środowiska}

Ważną rolę w zrozumieniu analizowanego zagadnienia przypada pojęciu przedmiotu uprawnień, czyli środowisku. W przypadku tego terminu wypada się zgodzić, iż jest to pojęcie nieostre. Jego definicje czasami znacznie się różnią, w zależności od dyscypliny naukowej, na potrzeby której jest rozpatrywany ${ }^{14}$. Warto pamiętać, iż w nauce prawa pojęcie środowiska będzie zawsze węższe od rozumienia tego terminu w naukach przyrodniczych ${ }^{15}$. Wynika to z innych celów i innego aspektu zainteresowania poszczególnych dyscyplin naukowych zajmujących się środowiskiem. Wypada się zgodzić, iż zakres prawny omawianego terminu, zgodnie z zasadą, że „prawo jest żywe”, będzie zmienny. Będzie on zależał

11 Ibid.

12 Afrykańska Karta Praw Człowieka i Ludów z dnia 26 czerwca 1981 r., OAU Doc. CAB/LEG/ 67/3/Rev. 5.

13 W.E. LANGLEY, Environment (w:) Encyclopedia of Human Rights Issues since 1945, London Chicago 1999, s. 111.

14 M. Górski (w:) Ustawa - Prawo Ochrony Srodowiska. Komentarz, Jendrośka J. (red.) Wrocław 2001, s. 81 i n.; J. Boć, E. Samborska-Boć, Ochrona Środowiska, Wrocław 2002 r., wyd. IV, s. 45 i n.; B. WierzBowski, B. Rakoczy, Podstawy prawa ochrony środowiska, wyd. I, Warszawa 2004, s. $15-17$.

15 J. Boć, E. Samborska-Boć, op. cit., s. 46. 
zarówno od specyfiki społeczno-gospodarczo-środowiskowej danego państwa, jak również od poziomu rozwoju, które dane pokolenie osiągnie.

Wydaje się, iż bez wikłania się w spory, wystarczy posłużyć się definicją zawartą $w$ ustawie Prawo ochrony środowiska ${ }^{16} \mathrm{w}$ art. 3. Zatem na potrzeby niniejszej pracy przez środowisko rozumie się ogół elementów przyrodniczych, w tym także przekształconych w wyniku działalności człowieka, a w szczególności powierzchnię ziemi, kopaliny, wody, powietrze, zwierzęta i rośliny, krajobraz oraz klimat. Wyliczenie elementów przyrodniczych ma charakter przykładowy. Następnie wypada podkreślić, iż definicja legalna obejmuje zarówno elementy przyrodnicze, przekształcone w wyniku działalności człowieka, jak i inne elementy przyrodnicze. W doktrynie uznaje się, iż definicja nie obejmuje elementów pozaprzyrodniczych, które najprawdopodobniej powinno się pojmować jako elementy powstałe w wyniku działalności człowieka ${ }^{17}$. Powstaje jednak dosyć sporna kwestia: kiedy mamy do czynienia jeszcze z elementami przekształconymi, a kiedy już z elementami „stworzonymi” przez człowieka. Zarówno w rozważanym przepisie ustawy, jak i w literaturze przedmiotu ostro zarysowuje się odrębność czlowieka od przyrody. Jest to jeden z bardziej typowych fundamentów kultury europejskiej. Powstaje pytanie, czy aby na pewno ten fundament jest godny podkreślania przy rozważaniu ochrony środowiska. To właśnie wyobcowanie człowieka i wyobrażenie, iż człowiek może sobie poradzić bez otaczających go elementów przyrodniczych spowodowało i powoduje potężne zniszczenia ekologiczne. Koncepcja człowieka jako elementu przyrody jest znacznie lepszą podbudową dla zrównoważonego rozwoju. Oczywiście z naszego punktu widzenia człowiek jest najważniejszym elementem przyrody.

\section{Prawo do środowiska}

Po zdefiniowaniu środowiska zastanówmy się nad prawem do środowiska pomińmy chwilowo przymiotnik „czyste”. Początkowo zarówno prawodawcy, jak i przedstawiciele doktryny formułowali jedno prawo do środowiska. Wraz jednak z rozwojem tej koncepcji zaczęto konstruować bardziej szczegółowe uprawnienia człowieka w tym obszarze. Prawo do środowiska zaczęło być rozbijane na mniejsze elementy. Obecnie można zauważyć, iż mamy raczej do czynienia z kompleksem praw, aniżeli z jednym prawem. Dlatego mówienie o prawie do środowiska jest pewnym uproszczeniem, które korzysta z tradycyjnego określenia przez doktrynę rozważanej kwestii ${ }^{18}$.

16 Ustawa z dnia 27 kwietnia 2001 r. Prawo ochrony środowiska, (Dz. U. Nr 62, poz. 627; ze zm.)

17 J. Boć, E. Samborska-Boć, op. cit., s. 52 .

18 W pracy autor posługując się zamiennie terminem prawo do środowiska, prawami środowiskowymi, prawami do środowiska, prawo do czystego środowiska, mając na myśli grupę praw do środowiska 
Na potrzeby niniejszej pracy można zatem przyjąć, iż na prawo do środowiska składa się grupa praw człowieka odnoszących się do środowiska. Przykładowo można wymienić takie prawa, jak:

- Prawo do korzystania z wartości środowiska ${ }^{19}$ w celach nie mających charakteru gospodarczego;

- Prawo do informacji o środowisku ${ }^{20}$;

- Prawo do uczestniczenia w podejmowaniu decyzji o środowisku ${ }^{21}$;

- Prawo do życia w środowisku zapewniającym zdrowie zarówno fizyczne jaki i psychiczne ${ }^{22}$.

Z pewnością nie jest to zamknięty katalog ${ }^{23}$ a proces rozpoznawania nowych praw człowieka odnoszących się do jego środowiska nie jest zakończony.

\section{Istota prawa do czystego środowiska}

Niezmiernie ważne jest zrozumienie co kryje się pod terminem prawo do czystego środowiska. Skupmy się na tym co może oznaczać dookreślenie środowiska poprzez przymiotnik „czyste”. Na podstawie analizy dotychczasowego dorobku w tym zakresie można wyróżnić dwa znaczenia tego sformułowania. Po pierwsze może to być kompleks praw człowieka do środowiska, bez wnikania w poziom tych praw, czyli będziemy mieli do czynienia z synonimem prawa do środowiska zdrowego, prawem do środowiska odpowiedniego, itp. Jak można zauważyć, jest to dominujący pogląd w literaturze przedmiotu ${ }^{24}$.

Po drugie można termin ten rozumieć dosłownie, czyli jako kompleks praw człowieka do środowiska, które nie jest dotknięte na tyle dużym zanieczyszczeniem pochodzenia antropologicznego, aby mogło godzić w człowieka. W tym przypadku mamy niezwykle wysoki poziom uprawnień. W doktrynie niektórzy zdają się rozróżniać prawo do czystego środowiska w brzmieniu literalnym ${ }^{25}$.

Być może sięgnięcie do dorobku prawnego pozwoli na obranie któregoś z kierunków rozumienia rozpatrywanego prawa. Zarówno akty wiążące prawa między-

19 W tym również prawo do turystyki szerzej: D. Walentynowicz, Wspólczesne funkcje turystyki w aspekcie integracji europejskiej (w:) Człowiek a tożsamość w procesie integracji Europy, B. Sitko $\mathrm{i}$ inni (red.), Olsztyn 2004, s. 416-423

20 Szerzej J. Jendrośka (w:) Ustawa - Prawo Ochrony Środowiska. Komentarz, Jendrośka J. (red.) Wroclaw 2001, s. $132 \mathrm{i} \mathrm{n.}$

21 Ibid., s. 225 i n.

22 B. HoŁyst, Promocja zdrowia psychicznego w zjednoczonej Europie (w:) Czlowiek a tożsamość w procesie integracji Europy, B. Sitko i inni (red.), Olsztyn 2004, s. 39-54

23 Wydaje się, iż do katalogu praw środowiskowych również można zaliczyć prawo do żywności niezmodyfikowanej i prawo do integralności genetycznej - A. Michalska, T. Twardowski, Prawo czlowieka do integralności genetycznej, Państwo i Prawo, Nr 5/1999

24 M.M. Kenig-Witkowska, op. cit., s. 27

25 Wierzbowski B., Rakoczy B., op. cit., s. 17 
narodowego, deklaracje jak i inne dokumenty prawa międzynarodowego, odnosząc się do materii praw człowieka w sferze środowiska, używają różnych sformułowań. I tak możemy się spotkać z prawem do satysfakcjonującego, odpowiedniego środowiska ${ }^{26}$, prawem do środowiska o jakości pozwalającej na życie w godności i dobrobycie $^{27}$, prawa do bezpiecznego, zdrowego i ekologicznego środowiska ${ }^{28}$. Również regulacje wewnętrzne państw operują różnymi określeniami. I tak w Czechach zostało proklamowane prawo do korzystnego środowiska ${ }^{29}$, w Hiszpanii mamy do czynienia z prawem do korzystania ze środowiska odpowiedniego dla rozwoju osobistego $0^{30}$, ustawodawstwo ukraińskie formuluje prawo do środowiska, które jest bezpieczne dla życia i zdrowia ${ }^{31}$, natomiast w Angoli mamy do czynienia z prawem do życia w zdrowym i czystym środowisku ${ }^{32}$. Nie można pozbyć się wrażenia, że im bardziej zamożne państwo, tym bardziej jego prawodawca unika precyzyjnej i stanowczej deklaracji w omawianym obszarze. Aczkolwiek państwo takie podejmuje znaczne wysiłki zmierzające $\mathrm{z}$ jednej strony do ochrony środowiska, a z drugiej strony do ochrony praw człowieka. Z kolei im społeczeństwo i państwo jest w mniejszym stopniu zamożne i mniej rozwinięte gospodarczo, tym literalne brzmienia prawa do środowiska uzyskuje silniejszy wymiar w aktach konstytucyjnych. W przypadku drugiej kategorii państw przepisy te mają charakter wybitnie deklaratywny i zazwyczaj nie podejmuje się działań publicznych, które by zmierzały do zapewnienia realizacji zagwarantowanego prawa.

Również w piśmiennictwie powszechnie stosuje się zamiennie różne zwroty dla określenia praw człowieka do środowiska. Bardzo często, używa się skrótów myślowych i kompleks praw do środowiska nazywa się prawem do środowiska zdrowego, prawem do środowiska czystego, prawem do środowiska odpowiedniego, czy właściwego.

Niektórzy przedstawiciele nauki twierdzą, iż mamy do czynienia z synonimami ${ }^{33}$. Takie stanowisko jest w pełni uzasadnione różnicami kulturalnymi, społecznymi i ekonomicznymi różnych państw. Jednak wykładnia literalna wydaje się przeczyć takiemu stanowisku. Nie można pozbyć się wrażenia, że powyżej wspominane prawa to dosyć bliskie znaczeniowo, aczkolwiek różne uprawnienia. Wynika to nie tylko z literalnego brzmienia zwrotów. Wraz z rozwojem cywiliza-

26 Afrykańska Karta Praw Człowieka i Ludów.

27 Deklaracja Sztokholmska.

28 Projekt Deklaracji o Zasadach Praw Człowieka i Środowisku z 1994 r., http://www.umn.edu

29 Art. 35 Konstytucji Czech z 1992 r., za J. M. Wagner i inni, Human rights and the environment, Materials for the 60-th session of the United Nation Commission on Human Rights, Geneva, 15 March - 32 April 2004, s. 63.

30 Art. 45 Konstytucji Hiszpańskiej z 1978 r., za J. M. Wagner i inni, Human rights..., s. 76.

31 Art. 50 Konstytucji Ukrainy z 1996 r., za J. M. Wagner i inni, Human rights..., s. 78.

Art. 24 Konstytucji Angoli z 1992 r., J. M. Wagner i inni, Human rights..., s. 57.

3 M.M. Kenig-WitKowsKA, op. cit., s. 27. 
cji odkrywane prawa człowieka są coraz bardziej wyrafinowane. Wraz ze wzrostem świadomości ekologicznej ludzkość, zarówno w wymiarze kolektywnym jak i jednostkowym, domaga się coraz lepszego zabezpieczenia jej otoczenia. Zatem można wysunąć pogląd, że dzięki postępowi dążymy do osiągnięcia coraz wyższego standardu życia, a to oznacza, iż niezbędnym się okazuje stopniowy wzrost poziomu praw do środowiska. O ile początkowo wystarczyło dla człowieka prawo do środowiska o minimalnym standardzie wystarczającym na przeżycie, o tyle dzisiaj wypada rozważyć czy człowiek nie powinien mieć prawa na wyższym poziomie, czyli prawa do czystego środowiska. W obecnych stosunkach prawo to wydaje się mieć charakter najwyższej wartości spośród wymienionych w analizowanym obszarze. Jednak czy ludzkość osiągnęła już wystarczający rozwój, aby umieścić prawo o takim zakresie w swoim dorobku?

Odpowiedź na to pytanie jest niezwykle prosta. Otóż dosyć powszechnie uznawanym korelatem prawa do środowiska jest obowiązek poszanowania, ochrony środowiska. Jeżeli człowiek potrafi wywiązać się z obowiązku ochrony środowiska, to zarazem powinno przysługiwać mu prawo do czystego środowiska. Niestety wydaje się, iż społeczeństwo zarówno na szczeblu międzynarodowym, jak i regionalnym nie jest przygotowane na taki poziom uprawnień, ponieważ nie jest w stanie wywiązać się ze wspomnianego obowiązku ${ }^{34}$. Warto jednak podkreślić, iż obowiązkiem państw i społeczności międzynarodowej powinno być zmierzanie do zagwarantowania prawa do czystego środowiska. Dlatego należy się liczyć z tym, iż z pewnością w przyszłości pojawi się wyższy poziom uprawnień dla człowieka w rozważanej sferze.

\section{Uprawnione podmioty}

Rozpatrując środowisko jako przedmiot uprawnień wypada zwrócić uwagę na dwa znaczenia, jakie w tym kontekście można wyróżnić.

Po pierwsze środowisko ma wymiar indywidualny. Można rozpatrywać otoczenie każdego człowieka z osobna. Poszczególni ludzie, mając zróżnicowane cechy społeczne i fizyczne, różny styl życia, w konsekwencji posiadają zróżnicowany zakres potrzeb w stosunku do środowiska ${ }^{35}$. Przedstawiciele nauki podkreślają, iż ze względu na indywidualizm jednostek ludzkich w sferze potrzeb środowiskowych, system prawny nie jest w stanie zapewnić prawa do indywidualnego środowiska w pełnym zakresie ${ }^{36}$. Nie oznacza to, iż prawodawca całkowicie unika gwarantowania praw indywidualnych $w$ analizowanym obszarze. Przykładowo polski system prawny zapewnia dosyć szeroką ochronę prawa indywidualnego

\footnotetext{
34 Oczywiście istnieją społeczności lokalne, czy nawet krajowe, które potrafią znacznie się zbliżyć do tego, aby zapewnić dla swoich obywateli analizowane prawo - np. państwa skandynawskie.

35 HoŁYst B., op.cit., s. 40

36 Sommer, op. cit., s. 962
} 
poprzez np.: prawo do informacji, prawo do uczestniczenia, prawo do zdrowia, prawo własności.

Po drugie środowisko można rozpatrywać na poziomie powszechnym i posiada ono wtedy wymiar ogólnospołeczny. Takie rozumienie sprowadza się do tego, że prawo do środowiska jest prawem kolektywnym i przysługuje, w najszerszym zakresie społeczności międzynarodowej, a w najwęższym społecznościom lokalnym. Realizacja kolektywnego prawa do środowiska powinna zapewnić zrównoważony rozwój, czyli niezakłócone funkcjonowanie elementów społecznych, ekonomicznych i środowiskowych. Inaczej rzecz ujmując, prawo kolektywne powinno gwarantować warunki przyrodnicze niezbędne do istnienia gatunku ludzkiego. Adresatem tego prawa nie jest jednostka ludzka, lecz ludzie jako gatunek.

Specyficzne dla prawa do czystego środowiska jest to, iż podmiotami uprawnionymi będą nie tylko ludzie obecnie żyjący. Dosyć istotne jest przyznanie analizowanego prawa przyszłym pokoleniom. Wyrażenie expressis verbis jako beneficjentów ludzi jeszcze nie narodzonych znacznie wyróżnia prawo do środowiska od innych praw ${ }^{37}$.

\section{Aspekt międzynarodowy}

Powiązanie ochrony środowiska z prawami człowieka jest problematyką, która swój ogromny rozwój zawdzięcza prawu międzynarodowemu. Z jednej strony deklarowanie coraz większej liczby praw człowieka, z drugiej strony bujny rozwój regulacji międzynarodowych dotyczących środowiska w sposób naturalny doprowadziło do tego, iż pojawił się wspólny obszar dla tych dwóch zagadnień. Przedstawiciele nauki rozpoczęli poszukiwać stycznych, które zmierzałyby do z jednej strony do lepszej realizacji praw człowieka z drugiej do wzmocnienia wysiłku nakierowanego na osiągnięcie celów w sferze ochrony środowiska. W dokumentach prawa międzynarodowego przez pryzmat praw człowieka na środowisko spojrzano juz w latach 60-tych. W rezolucji Zgromadzenia Ogólnego Narodów Zjednoczonych z dnia 3 grudnia 1968 r. zauważono, iż degradacja środowiska niesie negatywne skutki dla warunków życia człowieka, a tym samym prowadzi do naruszenia podstawowych praw człowieka ${ }^{38}$. Również w $1968 \mathrm{r}$. odbyła się konferencja w Teheranie, na której podkreślono, iż najnowsze zdobycze cywilizacji oraz rozwój nowych technologii, może zagrozić prawom i wolnościom człowieka ${ }^{39}$. Skupienie uwagi społeczności międzynarodowej na sprawach

\footnotetext{
37 Dekalracja Sztokholmska; art. 3 pkt 50 ustawy Prawo ochrony środowiska; art. 59 Konstytucji Albanii z 1998 r.; art. 225 Konstytucji Brazylii z 1998 r. za J. M. Wagner i inni, Human rights...

38 Rezolucja Zgromadzenia Ogólnego Narodów Zjednoczonych nr 2398 (XXII) z dnia 3 grudnia $1968 \mathrm{r}$.

39 M.M. KENIG-WitKowska, op. cit., s. 27.
} 
ochrony środowiska w 1972 r. na konferencji w Sztokholmie spowodowało zainteresowanie również aspektem praw jednostki w tym obszarze. W Deklaracji Sztokholmskiej sformułowano istnienie bezpośredniego związku pomiędzy prawami człowieka i jego środowiskiem. Pierwsza zasada głosi, iż: „Człowiek ma podstawowe prawo do wolności równości i odpowiednich warunków życia w środowisku o jakości pozwalającej na życie w godności i dobrobycie. Ponosi on zarazem odpowiedzialność za chronienie i ulepszanie środowiska dla obecnych i przyszłych pokoleń.” Tak zdecydowane sformułowanie oznaczało uznanie przez społeczność międzynarodową prawa człowieka do środowiska jako zasady powszechnie akceptowanej.

Deklaracja Sztokholmska, nie mając rangi dokumentu wiążącego strony, wywarła znaczący wpływ na regulacje wewnętrzne państw jak i w mniejszym stopniu na prawo traktatowe. Większość państw w swoich aktach zasadniczych odnosi się do rozważanej kwestii. Natomiast jeżeli chodzi o szczebel międzynarodowy, to wymienić należy takie akty wiążące, jak: Afrykańska Karta Praw Człowieka i Ludów z 1981 r. oraz Protokół dodatkowy do Amerykańskiej Konwencji Praw Człowieka dotyczący Praw Gospodarczych, Społecznych i Kulturalnych z 1988 r.

Prawo człowieka do czystego środowiska spotkało się z niezwykle pozytywnym oddźwiękiem w piśmiennictwie ${ }^{40}$. Zaczęto rozwijać nową ideę. Aby umocnić koncepcję poszukiwano podstaw w prawie wiążącym państwa. Nawiązywano do podstawowych umów międzynarodowych z zakresu praw człowieka. Ani Międzynarodowy Pakt Praw Obywatelskich i Politycznych ${ }^{41}$, ani Międzynarodowy Pakt Praw Gospodarczych, Społecznych i Kulturalnych ${ }^{42}$ nie wspomina bezpośrednio o rozważanej kwestii. W czasach, w których powstawały obie umowy prawo człowieka do środowiska nie było przedmiotem rozważań. W konsekwencji nie zostało ono włączone do pakietu podstawowych praw. Jednak wraz z odkryciem powiązań pomiędzy środowiskiem i prawami człowieka powstała potrzeba oparcia się na regulacjach wiążących. Dlatego też zaczęto interpretować postanowienia obu aktów w sposób daleko odbiegający od literalnego brzmienia. Wykładnia celowościowa zmierza bądź do poszerzenia znaczenia jednego z praw I generacji - prawa do życia ${ }^{43}$, bądź do szerokiej inter-

${ }^{40}$ Potężny dorobek polski, np. publikacje: G. Grabowskiej, M.M. Kenig-Witkowskiej, R. Paczuskiego, J. Sommera, W. Radeckiego, J. Ciechanowicz; z innych: K. Bosselmann, Human Rights and the Environment: Redefining Fundamental Principles?, http://www.arbld. unimelb.edu.au i cytowana tam literatura; J. L. Sax, The search for Environmental Rights (w:) Environmental Decisionmaking, wyd. III, R. L. Fischman, M.S. Squillace (red.), s. 35-42.

41 Międzynarodowy Pakt Praw Obywatelskich i Politycznych z 19 grudnia 1966 r.

42 Międzynarodowy Pakt Praw Gospodarczych, Społecznych i Kulturalnych z 19 grudnia 1966 r.

43 Art. 6 Międzynarodowy Pakt Praw Obywatelskich i Politycznych. 
pretacji praw II generacji, zwłaszcza prawa do odpowiedniego poziomu żcia ${ }^{44}$ oraz prawa do korzystania z najwyższego osiągalnego poziomu ochrony zdrowia fizycznego i psychicznego ${ }^{45}$. Na uwagę zasługuje rola jaką odgrywa Komitet Praw Człowieka w omawianej materii. W „Uwagach ogólnych” z dnia 27 lipca 1982 r. stwierdzono, iż prawo do życia jest fundamentem wszelkich praw człowieka. Komitet Praw Człowieka podkreślił, iż z prawa tego wynikają między innymi: prawo do ochrony przed ryzykiem katastrofy nuklearnej, prawo do warunków higienicznych i ochrony środowiska, system ochrony zdrowia ${ }^{46}$. Nie poprzestając na tym, uznano, iż prawo do życia obejmuje nie tylko obowiązek państw od powstrzymania się od wszelkich działań godzących w prawa, lecz również obowiązek działania w celu zagwarantowania praw ${ }^{47}$. Tak daleko idąca wykładnia nie jest aprobowana przez państwa. Ponadto prawo do życia jest traktowane jako prawo do przeżycia, tak np. w Deklaracji o Postępie Społecznym i Rozwoju uchwalonej przez Zgromadzenie Ogólne Narodów Zjednoczonych w 1969 r.. Wypada dodać, iż orzecznictwo Komitetu nie wiąże stron Międzynarodowego Paktu Praw Obywatelskich i Publicznych i należy traktować je jako „pogląd”48. Aczkolwiek warto zauważyć, iż prezentowana postawa znacząco sprzyja umacnianiu prawa człowieka do czystego środowiska.

Od pewnego czasu na arenie międzynarodowej na pierwszy plan w omawianym obszarze wysuwają się zmagania pomiędzy prawami człowieka a interesami wielkich korporacji gospodarczych. Wielkie międzynarodowe przedsiębiorstwa mają zazwyczaj jeden cel, czyli uzyskanie dochodu. Zysk jest bezsprzecznie jednym z najważniejszych elementów prowadzenia działalności gospodarczej i jego eliminacja nie ma żadnych racjonalnych podstaw. Wypada zauważyć, iż obecny poziom cywilizacyjny nie pozwala na istnienie drapieżnych organizacji gospodarczych. Zysk nie jest już jedynym wyznacznikiem sukcesu. Prowadzenie działalności gospodarczej jest kształtowane nie tylko tradycyjnymi elementami otoczenia. Prawa człowieka od dawna już były wyznacznikami granic wolności gospodarczej. Jednak dopiero od kilkunastu lat daje się zauważyć powoływanie się na prawa środowiskowe ${ }^{49} \mathrm{~W}$ sporach przede wszystkim z międzynarodowymi korporacjami. Interesujące jest to, iż niechęć zwraca się przede wszystkim przeciwko międzynarodowym przedsiębiorstwom. Wynika to z kilku powodów:

${ }^{44}$ Art. 11 Międzynarodowy Pakt Praw Gospodarczych, Społecznych i Kulturalnych.

45 Art. 12 Międzynarodowy Pakt Praw Gospodarczych, Społecznych i Kulturalnych.

46 A. Michalska, Komitet Praw Czlowieka. Kompetencje, funkcjonowanie, orzecznictwo, Warszawa 1994, s. 120-122.

47 Powstał kolejny problem: czy mamy do czynienia z obowiązkami rezultatu czy tylko obowiązkami działania.

48 Ibid., s. 175-176.

49 Np. strony internetowe http://www.sierraclub.org 
podmioty te nie są zazwyczaj w żaden sposób związane z krajem, w którym prowadzą rabunkową gospodarkę, a zatem nie liczą się również z uwarunkowaniami społecznymi, ekonomicznymi, czy środowiskowymi danego kraju. Najczęściej łamanie praw środowiskowych jest połączone z łamaniem praw politycznych i ekonomicznych. Dlatego też zagwarantowanie praw środowiskowych prowadzi do lepszej realizacji innych praw człowieka. Obecne realia wskazują na to, iż zwłaszcza państwa rozwijające są zbyt słabe, aby samotnie przeciwstawić się potężnym interesom. Krajowe regulacje prawne odnoszące się do ochrony środowiska są zbyt lagodne albo nie są stosowane. Człowiek zaczyna być obywatelem świata, a to oznacza zmiany w tradycyjnym podejściu do podmiotowości międzynarodowej ${ }^{50}$. Dlatego też coraz częściej doktryna dostrzega potrzebę ustanowienia międzynarodowych mechanizmów, które by gwarantowały prawa człowieka do życia w czystym środowisku

Wprowadzeniu wiążących instrumentów na arenie międzynarodowej sprzyja działanie agend ONZ i innych podmiotów związanych z ONZ. Szczególne znaczenie w wymiarze międzynarodowym w zakresie rozwoju prawa człowieka do czystego środowiska należy przypisać dwóm organizacjom. Po pierwsze przewodnikowi w zakresie ochrony praw - Komitetowi Praw Człowieka oraz po drugie liderowi ekologii - Programowi Narodów Zjednoczonych ds. Środowiska. W ramach ONZ w 1989 r. zainicjowano pracę w Podkomisji ds. zapobiegania dyskryminacji i ochrony mniejszości. Końcowy raport Fatma Zohra Ksentini na temat powiązań pomiędzy prawami czlowieka a środowiskiem został przygotowany w $1994 \mathrm{r}^{52}$. W dokumencie tym miedzy innymi przedstawiono prawne podstawy środowiskowych praw człowieka. Raport spowodował, że rozważana problematyka stała się przedmiotem żywych dyskusji w kontekście unormowania międzynarodowego ${ }^{53}$. W tym też roku przygotowano projekt Deklaracji o Zasa-

50 Szerzej na temat podmiotowości w prawie międzynarodowym - Wierzbicki B. Podmioty prawa międzynarodowego (w:) Prawo międzynarodowe publiczne (red.) Wierzbicki B., Białystok 1997, s. 51 i n.; Jest jeszcze dosyć daleko do tego, aby uznać na arenie międzynarodowej człowieka jako podmiot równy państwom, czy organizacjom międzynarodowym - G. Grabowska, Podmioty prawa międzynarodowego (w:) Wielka encyklopedia prawa, (red.) Smoktunowicz E., s. 656. Jednak coraz szersze proklamowanie praw w aktach międzynarodowych oraz odwoływanie się do poszczególnych grup społecznych wskazuje na zwiększające się znaczenie człowieka zarówno jako odrębnej istoty ludzkiej, jak i członka różnych grup - np. Agenda 21, czy Johhanesburg Summit 2002 Brochure.

51 G. MAGGio, O. J. Lynch, Human Rights, Environment, and Economic Development: Existing and Emerging Standards in International Law and Global Society, http://www.ciel.org

${ }_{52}$ Final Report to Sub-Commission, E/CN.4/Sub.2/1994/9.

53 Np. Wspólne seminarium Komitetu Praw Człowieka, Programu Narodów Zjednoczonych ds. Środowiska i Biuro Wysokiego Komisarza ds. Praw człowieka, które odbyło się w Genewie w 2002, http://www.unhchr.ch, Sześćdziesiąta sesja Komitetu Praw Człowieka Geneva, 15 March - 32 April 2004. 
dach Praw Człowieka i Środowisku ${ }^{54}$. Niestety nie została ona powszechnie przyjęta. Wydaje się, iż mechanizmy kontrolne powinny być wzmocnione poprzez kodyfikację.

Wypada zauważyć, że na arenie międzynarodowej rośnie zrozumienie, iż pełne cieszenie się prawami człowieka wymaga podkreślenia szerokiego znaczenia problematyki środowiska ${ }^{55}$.

\section{Aspekt Polski}

W prawie polskim fundamentalnym aktem, dla każdej normowanej dziedziny życia jest ustawa zasadnicza. Polska posiada duży dorobek w przypadku konstytucyjnego normowania prawa człowieka do srodowiska. Rozważanej sprawie znowelizowana Konstytucja PRL ${ }^{56}$ poświęcała przepis art. 71, zamieszczony w rozdziale 8 , dotyczącym podstawowych praw i obowiązków obywateli. Stanowił on, iż „Obywatele Rzeczypospolitej Polskiej mają prawo do korzystania z wartości środowiska naturalnego oraz obowiązek jego ochrony”.

Od 76 r. obywatele uzyskali silny argument przemawiający za posiadaniem przez nich uprawnień do środowiska i to naturalnego. Trudności z określeniem charakteru prawa przewidzianego w Konstytucji pojawiły się już w okresie obowiązywania komentowanego przepisu ${ }^{57}$. Trybunał Konstytucyjny ${ }^{58}$ orzekł, iż: „... Konstytucja ma tu niewątpliwie na myśli środowisko odpowiadające standardom środowiska odpowiedniej jakości i o zapewnionej równowadze ekologicznej. Prawu temu odpowiada zarazem obowiązek obywateli (i innych podmiotów) ochrony środowiska naturalnego. W przepisie tym zakotwiczona jest także, jako swoista jego funkcja, troska państwa o jakość środowiska naturalnego i stwarzanie warunków dla jego zachowania w należytym stanie dla współczesnych i przyszłych pokoleń...”

Należy jednak pamiętać, że taka interpretacja przywołanej normy konstytucyjnej wynikała przede wszystkim z treści preambuly do ustawy z dnia 31 stycznia 1980 r. o ochronie i kształtowaniu środowiska ${ }^{59}$.

Z dzisiejszego punktu widzenia należy wysnuć wniosek, iż prawo do naturalnego środowiska, jest najdalej posuniętą ochroną człowieka w omawianej sferze. Niestety w dzisiejszej dobie, kiedy w niemal wszystkich zakątkach świata mamy do czynienia z wpływem antropologicznym, trudno stwierdzić, iz jakiekolwiek państwo ma realne możliwości zapewnienia prawa do naturalnego środowiska.

\footnotetext{
54 Projekt Deklaracji o Zasadach Praw Człowieka i Środowisku z 1994 r., http://www.umn.edu

55 J. Martin Wagner i inni, op. cit., s. 4.

56 Konstytucja z 22 lipca 1952 r., (Dz.U. t. j. z 1976 r., Nr 7, poz., 36).

57 Np. Sommer, op. cit., s. 962 i n. i cytowana tam literatura.

58 Orzeczenie TK $\mathrm{z}$ dnia 17 grudnia 1991 r. Nr U. 2/91, http://www.trybunal.gov.pl .

59 Ibid.
} 
Omawianemu przepisowi zarzucono ${ }^{60}$ to, iż jego realna skuteczność była niewielka, zwłaszcza ze względu na brak określenia gwarancji wykonalności, zapewniającej skuteczną egzekucję ${ }^{61}$.

W tekście obecnie obowiązującej Konstytucji z dnia 2 kwietnia 1997 r. nie powtórzono za poprzednią ustawą zasadniczą prawa podmiotowego obywatela ${ }^{62}$ do korzystania z wartości środowiska naturalnego. Brak bezpośredniego sformułowania powoduje, iż należy się zastanowić z jakimi uprawnieniami w omawianej sferze mamy obecnie do czynienia na tle polskich regulacji prawnych. Czy możemy mówić o jakimkolwiek prawie do środowiska? Czy jest to prawo podmiotowe, czy może jedynie prawo deklaratywne ${ }^{63}$ ? Jaki jest zakres uprawnień? Jaki jest stosunek pomiędzy państwem a jednostką ludzką?

W omawianym przypadku należy podkreślić dwa zagadnienia. Po pierwsze ustawa zasadnicza posiada szczególne znaczenie dla praw człowieka i obywatela w wymiarze krajowym. Po drugie w polskiej konstytucji przywiązano znaczną wagę do ochrony środowiska. Powiązanie tych dwóch zagadnień daje pełny obraz konstytucyjnych ram prawa człowieka do czystego środowiska.

Pierwsze odniesienia do analizowanej problematyki spotykamy już w tekście preambuły. Pomimo tego, iż istnieją dwa odmienne poglądy dotyczące mocy obowiązywania postanowień preambuły ${ }^{64}$, to jednak należy zauważyć, iż ich znaczenia nie sposób nie docenić.

Jednym z podstawowych celów konstytucji jest zagwarantowanie praw obywatelskich.

Bezpośrednio wyrażone uzasadnienie wydania Konstytucji w postaci troski o byt i przyszłość Ojczyzny jest zwrotem który zawiera w sobie nie tylko elementy społeczne i ekonomiczne. W jego zakresie można dopatrzyć się również troski o obecny i przyszły stan środowiska naturalnego. Harmonijne połączenie wspomnianych czynników nasuwa wniosek, iż tylko zrównoważony rozwój może zapewnić stan, w którym Polskę czeka dalsza przyszłość. Równie ważne jest zobowiązanie, aby przekazać przyszłym pokoleniom „... wszystko co cenne, z ponad tysiącletniego dorobku.... Oznacza to, iż aktualnie żyjące pokolenie powinno dążyć do zachowania zarówno dorobku kulturowego, jak i walorów przyrodni-

${ }_{60}$ J. Boć, E. Samborska-Boć, op. cit., s. 54; J. Menkes, Prawo do środowiska jako prawo człowieka (w:) Ekologia i prawo, Lublin 1999, s. 47.

${ }_{61}$ L. GARDJAN-KAWA: Administrowanie zasobami środowiska po reformie ustrojowej, Warszawa 2000 , s. 24.

62 J. Boć, E. Samborska-Boć, op. cit., s. 54.

63 Autor nie rozważa tego wątku, szerzej na ten temat np. A. HAŁADY, Konstytucyjne prawo do korzystania z wartości środowiska, Prawo i Środowisko, Nr 2/2002; z kolei rozważania na temat publicznego prawa podmiotowego - W. JAKIMOWICZ, op. cit.

${ }^{64}$ W. KRĘcIsz, W. OrŁowski, Przygotowanie, uchwalenie i ogólna charakterystyka Konstytucji $z 1997$ r. (w:) SkrzydŁo W. (red.) Polskie prawo konstytucyjne, Lublin 1997, s. 119. 
czych, które zostały utrzymane do dzisiejszego dnia. W tym miejscu, zatem po raz pierwszy pojawia się prawo przyszłych pokoleń do środowiska.

Prawodawca wzywa do uznania - zachowania przyrodzonej godności ${ }^{65}$ człowieka, prawa do wolności oraz obowiązku solidarności z innymi - za „niewzruszoną podstawę Rzeczypospolitej Polskiej”. Analizując powyższą deklarację, można wysnuć wniosek, iż niemożliwe jest rozpatrywanie godności człowieka oraz obowiązku solidarności bez prawa do czystego, nieskażonego środowiska. Zatem wszyscy stosujący normy Konstytucji powinni dbać o godne życie człowieka w czystym ekologicznie otoczeniu ${ }^{66}$.

Bardziej bezpośrednie odniesienia do przedmiotu rozważań znajdziemy w części właściwej Konstytucji. Niezmiernie liczne zasady konstytucyjne można odnieść do prawa człowieka do środowiska, jak zasada sprawiedliwości społecznej, czy zasada przestrzegania wiążącego RP prawa międzynarodowego. Jednak najważniejszą jest ustrojowa zasada zrównoważonego rozwoju ${ }^{67}$. W art. 5 Konstytucji ujęto, iż „Rzeczpospolita Polska strzeże niepodległości i nienaruszalności swojego terytorium, zapewnia wolności i prawa człowieka i obywatela oraz bezpieczeństwo obywateli, strzeże dziedzictwa narodowego oraz zapewnia ochronę środowiska, kierując się zasadą zrównoważonego rozwoju." Zastanawiające jest czy kierowanie się zasadą zrównoważonego rozwoju odnosi się wyłącznie do ostatniego wymienionego pola działania państwa, czyli zapewnienia ochrony środowiska? Czy też zrównoważony rozwój powinien być brany pod rozwagę we wszystkich wymienionych sferach działania państwa? Literalne brzmienie wskazuje na to, iż wszystkie wymienione sfery działania państwa powinny odznaczać się wyważeniem elementów ekonomicznych, społecznych i środowiskowych. Konkludując zapewnienie przez RP wolności i praw człowieka i obywatela musi się odbywać zgodnie z zasadą zrównoważonego rozwoju. Celowość takiego pojmowania jest w pełni uzasadniona tym, iż realizacja praw istoty ludzkiej jest uzależniona od zapewnienia środowiska o odpowiedniej jakości. Zatem podstawą wszelkich praw będzie prawo istoty ludzkiej do korzystania ze środowiska.

65 Co zostało jeszcze dobitniej ujęte w art. 30 Konstytucji - szerzej na temat godności J. Zajadło, Godność i prawa czlowieka (ideowe i normatywne źródła przepisu art. 30 Konstytucji), Gdańskie Studia Prawnicze Nr 3/2000, s. 51-62.

66 Gardjan-Kawa L., op. cit., s. 24-32.

67 Art. 5 Konstytucji z 2 kwietnia 1997 r. (Dz. U. Nr 78, poz. 483); część doktryny traktuję zasadę zrównoważonego rozwoju jako zasadę ustrojową - M. KalLas, Konstytucja Rzeczpospolitej Polskiej, Warszawa 2001, s. 30-31; R. PACzuski, Zrównoważony rozwój w prawie i polityce ochrony środowiska Unii Europejskiej oraz jako zadanie państwa polskiego w świetle obowiazujacego ustawodawstwa (w:) Zeszyty naukowe WSHE, tom VI, Ochrona Srodowiska, Włocławek 2000, s. 32; odmiennie J. Ciechanowicz, L. Mering: Ochrona środowiska w Konstytucji RP (w :) Konstytucja Rzeczypospolitej Polskiej z 1997 roku a członkostwo Polski w Unii Europejskiej, Mik C. (red.), Toruń 1999, s. 474. 
Warto też uwzględnić ograniczenia w zakresie korzystania z konstytucyjnych wolności i praw mogą być ustanawiane tylko w ustawie i tylko wtedy, gdy są konieczne w demokratycznym państwie dla jego bezpieczeństwa lub porządku publicznego, bądź dla ochrony środowiska, zdrowia i moralności publicznej, albo wolności i praw innych osób. Oznacza to, iź środowisko stanowi walor, który nie tylko jest przedmiotem uprawnień, lecz również jest niezwykle ważną wartością publiczną.

Należy zaakcentować, iż nowa ustawa zasadnicza nie formułując bezpośrednio prawa do środowiska, jest oparta na realniejszych założeniach, aniżeli jej poprzedniczka. Jednak takiego sposobu regulacji omawianego obszaru nie można uznawać za wycofanie się przez państwo polskie z koncepcji zapewnienia rozważanego prawa z kilku powodów.

Po pierwsze brak normy oznaczałby, iż Polska cofnęla się w stosunku do osiągnięć Konstytucji PRL, nawet jeżeli były one deklaratywne. Warto również zwrócić uwagę na to, iż Trybunał Konstytucyjny ${ }^{68}$ uznał: „Prawo do korzystania przez obywateli ze środowiska naturalnego należy do podstawowych praw obywateli naszego kraju." Orzeczenie z 17 grudnia 1991 r. zostało wydane w nowej rzeczywistości ustrojowej, a zatem należy uznać, iż zachowuje swoją aktualność. Skoro prawo do środowiska jest jednym z podstawowych praw obywateli naszego kraju, to niezwykle trudno zgodzić się z tezą, iż wyłącznie utrata mocy wiążącej przez akty, które o nim bezpośrednio wspominały, jest wystarczającym argumentem przeciwko istnieniu tego prawa w polskim porządku prawnym.

Po drugie pomimo tego, że Konstytucja bezpośrednio nie wspomina o prawie do czystego środowiska, to wymienia inne prawa, które mogą być zaliczane do praw środowiskowych, jak np.:

- prawo do informacji o stanie i ochronie środowiska - art. 74 ust. 3 Konstytucji;

- prawo do wsparcia działania na rzecz ochrony i poprawy stanu środowiska - art. 74 ust. 4 Konstytucji;

- prawo do ochrony zdrowia poprzez zapobiegania negatywnym dla zdrowia skutkom degradacji środowiska - art. 68 ust. 4 w związku z art. 68 ust. 1 Konstytucji;

- prawo do składania petycji, wniosków i skarg w interesie publicznym, czyli np. w celu ochrony środowiska - art. 63 Konstytucji.

Po trzecie ustawodawca konstytucyjny przyjął $w$ artykule 74 ust. 2, iz: "Ochrona środowiska jest obowiązkiem władz publicznych" a w artykule 86: „Każdy jest obowiązany do dbałości o stan środowiska i ponosi odpowiedzialność za spowodowane przez siebie jego pogorszenie." Sięgnijmy w tym momencie

68 Orzeczenie TK z dnia 17 grudnia 1991 r. Nr U. 2/91. 
po proste rozumowanie. Jeżeli istnieje obowiązek to jego korelatem jest prawo. Zatem pozostaje się zastanowić kto będzie podmiotem uprawnionym. Opierając się na postanowieniach Konstytucji ${ }^{69}$ oraz dotychczasowym dorobku doktry$n y^{70}$ zarówno krajowym, jaki i międzynarodowym należy zauważyć, iż beneficjantem będzie co najmniej każdy kto znajduje się pod władzą Rzeczypospolitej Polskiej ${ }^{71}$.

Ponadto można podeprzeć się ustawodawstwem zwykłym w rozważanej kwestii $^{72}$. Próbę wyinterpretowania analizowanego prawa można oprzeć na art. 4 ust. 1 ustawy Prawo ochrony środowiska. Prawodawca wyszczególnił dwa rodzaje korzystania ze środowiska: korzystanie powszechne oraz korzystanie przekraczające korzystanie powszechne. Dla rozważanej tematyki korzystanie powszechne ma podstawowe znaczenie. „Powszechne korzystanie ze środowiska przysługuje z mocy ustawy każdemu i obejmuje korzystanie ze środowiska, bez użycia instalacji, w celu zaspokojenia potrzeb osobistych oraz gospodarstwa domowego, w tym wypoczynku oraz uprawiania sportu, w zakresie:

1) wprowadzania do środowiska substancji lub energii,

2) innych niż wymienione w pkt 1 rodzajów powszechnego korzystania $z$ wód w rozumieniu ustawy z dnia 18 lipca 2001 r. - Prawo wodne."

Cel korzystania powszechnego, czyli zaspokojenie potrzeb osobistych oraz gospodarstwa domowego wskazuje, iż podmiotami uprawnionymi będą jedynie osoby fizyczne.

Należy również zauważyć, iż literalne brzmienie wspomnianego przepisu posiada węższy zakres ${ }^{73}$ aniżeli zakres prawa obywateli do równoprawnego korzystania z wartości środowiska, które było deklarowane w preambule poprzednio obowiązującej ustawy ${ }^{74}$.

W związku z powyższym w pełni uzasadnione wydaje się stwierdzenie, iż Polska gwarantuje prawo do czystego środowiska w dosyć szerokim zakresie. Aczkolwiek zmiany wprowadzone Konstytucją oraz ustawą Prawo ochrony środowiska $z$ jednej strony skutkują, tym ze literalny zakres prawa do środowiska staje się węższy. Z drugiej strony prawodawca wprowadza instrumenty, które pozwalają urealnić ochronę rozważanego prawa.

69 Art. 1 in. oraz art. 30 i n. Konstytucji.

70 Np. J. НоєDA I Zв. HoєDA, op. cit., s. 38.

${ }^{71}$ Ściślej każdy kto korzysta z realizacji obowiązków w omawianej materii.

72 J. Machowski, Ochrona środowiska. Prawo i zrównoważony rozwój, Warszawa 2003, s. 73.

73 Szerzej na temat tego prawa - P. Mazur, Prawo osobiste do korzystania z wartości środowiska naturalnego, PiP nr 11/1999, s. 51 i n.

74 Nieobowiązująca ustawa $z$ dnia 31 stycznia 1980 r. o ochronie i kształtowaniu środowiska (Dz.U. z 1994 r., Nr 49, poz. 196). 


\title{
Zakończenie
}

Harmonijne połączenie elementów środowiskowych, ekonomicznych i społecznych leży w interesie ludzkości. Tylko zrównoważony rozwój daje w dłuższej perspektywie czasu możliwość realizacji praw człowieka. Prawo człowieka do czystego środowiska jest podstawą dzięki, której mogą być realizowane inne prawa. Powiązanie dwóch zagadnień praw człowieka i ochrony środowiska prowadzi do rozwoju demokracji. Omawiane zagadnienie jest dowodem na emancypacje człowieka jako podmiotu w stosunkach związanych ze środowiskiem. Nie tylko państwo chroni wartości przyrodnicze. Poprzez umacnianie się rozważanej koncepcji, czlowiek staje się gospodarzem, który posiada odpowiednie instrumenty do kształtowania swojego otoczenia. Człowiek staje się rzecznikiem interesu publicznego. Państwa w coraz większym stopniu zaczynają zdawać sobie sprawę, iż bez współpracy z obywatelami mogą ponieść fiasko w swoich działaniach. Społeczność międzynarodowa "upodmiotowiając" człowieka zyskuje pomoc dla realizacji celów w zakresie ochrony środowiska. Ugruntowanie się prawa do czystego środowiska to wzrost przyzwolenia i poparcia dla działań ekologicznych oraz rozwój społecznej świadomości ekologicznej.

\section{Human Rights and the Environment}

\author{
SUMMARY
}

There should be no doubt that human activities can cause serious environmental harms, or that those harms, in turn, often result in very grave consequences to human beings. Put positively, a clean and healthy environment is essential to the realization of fundamental human rights. Some advocates argue that the right to a clean environment belongs to third generation of rights. Others noted that it is separated fourth generation of rights. It is necessary to reflect on a source of environmental rights. It is important to search for the satisfactory meaning of right to a clean environment.

This article shows repeated and increasing recognition of a human rights-based approach to environmental protection. Such recognition demonstrates that environmental rights are emerging as an important component of international law and Polish law.

At the national and international levels the right to a healthy environment (or a related formulation) has played an important role in fostering connections between human rights and environmental approaches.

The increasing practice of substantively upholding and encouraging respect for the right to a clean environment is important and should be recognized and strengthened. 